\title{
Measurements of the HONO photodissociation constant
}

\author{
K. J. Wall · C. L. Schiller · G. W. Harris
}

\begin{abstract}
Measurements of the photodissociation constant for nitrous acid $\left(j_{\mathrm{HONO}}\right)$ were made at an urban site in Toronto, Canada, during the months of May-July 2005, using an optically thin actinometer. Operating details of the $j_{\text {HONO }}$ monitor are reported, along with laboratory tests. Measurements of $j_{\mathrm{HONO}}$ were obtained for solar zenith angles ranging from $20-75^{\circ}$, under clear and cloudy skies. Maximum error estimates on $j_{\text {HONO }}$ under clear skies range from $11 \%$ at sunrise, to $4 \%$ at solar noon, with a minimum detection limit of $5.7 \times 10^{-4} / \mathrm{sec}$ for our actinometer. Measured clear-sky values of $j_{\text {HONO }}$ were compared with values calculated by a four-stream discrete ordinate radiative transfer (RT) model (ACD TUV version 4.1), and were found to be within better than $10 \%$ agreement for solar zenith angles $<65^{\circ}$. For conditions of scattered cloud, enhancement and suppression of the $j_{\text {HONO }}$ values occurred by as much as $16 \%-70 \%$, and $59 \%-80 \%$, respectively. The integrated band area of the $n \pi^{*}$ transition for gas-phase nitrous acid yields an oscillator strength, $f=(1.06 \pm$ $0.044) \times 10^{-3}$ (based on clear-sky data), $19.1 \%$ higher than the value reported by Bongartz et al. (1991).
\end{abstract}

Keywords Actinic flux $\cdot$ Actinometer $\cdot$ Nitrous acid (HONO) $\cdot$ Radiative transfer model

\section{Introduction}

It has long been recognized that the photolysis of nitrous acid (HONO) is a potentially important production mechanism for hydroxyl radicals in the polluted urban atmosphere (Harris et al., 1982). In the wavelength range of $300-400 \mathrm{~nm}$, photolysis of HONO directly produces $\mathrm{OH}$ :

$\mathrm{HONO}+h v \rightarrow \mathrm{OH}+\mathrm{NO}$ 
The hydroxyl radical is central in the formation of ozone and is the most important oxidizing species in the daytime atmosphere. The hydroxyl radical source is of most importance during early morning when HONO concentrations may be high after night-time accumulation, and when $\mathrm{OH}$ production rates from other sources (photolysis of ozone and formaldehyde) are slow (Harris et al.,1982).

To better understand the production of $\mathrm{OH}$ from HONO photolysis, the determination of its photolysis frequency is as important as knowing the concentration of the trace species itself. The photolysis frequency, $j$, is determined for species $x$, by evaluating the following convolution product over all wavelengths:

$$
j_{x}=\int \sigma_{x}(\lambda) \Phi_{x}(\lambda) F(\lambda) d \lambda
$$

where $F(\lambda)$ is the spectral actinic flux (radiant flux density incident onto a spherical area) and $\sigma(\lambda)$ and $\Phi(\lambda)$ are, respectively, the absorption cross-section and the photodissociation quantum yield of the molecule $x$. The photolysis rate is directly proportional to the actinic flux rather than the irradiance since the global radiation incident on a volume of air can produce interactions between matter and photons (Madronich, 1987).

Experimentally, the direct measurement of spectral actinic flux is complicated, since a specific optical receptor characterized by a uniform angular sensitivity with accurate spectral response is required (Cotte et al., 1997). Spectroradiometers capable of recording actinic flux spectra in both the UV and visible regions only started being developed in the late 1990's (Junkermann et al., 1989, 2002; Van der Hage et al., 1994; Cotte, 1995; Müller et al., 1995; Kraus and Hofzumahaus, 1998, 2000; Hofzumahaus et al., 1999, 2002, 2004; Shetter and Müller, 1999; Balis et al., 2002; Shetter et al., 2002; Bais et al., 2003; Cantrell et al., 2003; Crawford et al., 2003; Holland et al., 2003; Kylling et al., 2005). Another approach to obtain the spectral actinic flux is to evaluate it theoretically using a radiative transfer model. Due to the numerous assumptions and uncertainties involved in the calculations, this computational radiative treatment is often inconvenient. As a result, the direct measurement of $\mathrm{j}$ is preferred. Only chemical actinometers (Junkermann et al., 1989; Shetter et al., 1992) directly measure photodissociation frequencies, by observing the respective photochemical process inside a closed UV-transparent cell. The decay of the reactant or the formation of products during a given time of exposure is then a measure of the respective $j$ value.

There are minimal experimental HONO photolysis data in the literature, thus, the primary aim of this work was the development and application of a correctly designed optically thin actinometer for the direct measurement of $j_{\text {HONO }}$. In this paper, operating details of the $j_{\text {HONO }}$ monitor are reported along with laboratory tests. The theoretical factors involved in calculating the quantity $j$ in a plug flow reactor are also examined. In addition, ambient $j_{\text {HONO }}$ measurements are reported for both clear and cloudy sky conditions. Comparison of experimental $j_{\text {HONO }}$ values by chemical actinometry is impossible as chemical actinometer measurements for the photolysis frequency of HONO are unavailable in the photochemical literature to date. As a result, accurate radiative transfer model estimates (ACD TUV version 4.1) are included in the comparison. 


\section{Experimental}

\subsection{HONO measurement technique}

A highly sensitive technique for the measurement of nitrous acid developed by Huang et al. (2002) was assembled and evaluated. The technique is based on aqueous scrubbing of nitrous acid in a neutral buffer, followed by derivatization of nitrite to a highly light-absorbing azo dye with sulfanilamide (SA) and (1-naphthyl)-ethylenediamine (NED) in acidic solution (Huang et al., 2002).

Quantitative collection was achieved using a neutral phosphate buffer solution (45-mM). The scrubbing solution was mixed with fresh SA/NED working reagent solution, and the mixture was passed through a reaction coil with a volume of approximately $2.5 \mathrm{~mL}$, allowing a derivatization time of approximately $5 \mathrm{~min}$. To correct for volume loss during scrubbing, potassium hydrogen phthalate was added to the scrubbing solution as an internal standard. The derivatized solution was loaded onto a $100 \mu \mathrm{L}$ sample loop (Rheodyne Inc.) using a 6-port electrically actuated auto-injection valve (Rheodyne Inc.). The sample was then separated on a $\mathrm{C}_{18}$ reverse-phase column $(5 \mu \mathrm{m}, 4.0 \times 150 \mathrm{~mm}$ analytical column, Waters $)$ and detected using a variable wavelength UV-VIS detector (Varian 9050) at $540 \mathrm{~nm}$. Isocratic elution was accomplished with $25 \%$ acetonitrile in $15-\mathrm{mM} \mathrm{HCl}$ at a flow rate of $1.3 \mathrm{~mL} / \mathrm{min}$ using an HPLC pump (Varian 9010). Sampling time was limited by the chromatographic run-time of approximately $8.5 \mathrm{~min}$. The system was automated using Borwin Software, which controlled sample injection and acquired chromatographic data.

The precision on a 20 ppbv HONO sample, similar in concentration to the input HONO sample used in this experiment, was evaluated in the laboratory prior to ambient measurements. A precision of $0.25 \%$ was determined for the input HONO sample using the HONO measurement technique.

\subsection{HONO generation system}

The HONO generation system used is based on the system developed by Febo et al. (1995):

$\mathrm{HCl}(\mathrm{g})+\mathrm{NaNO}_{2}(\mathrm{~s}) \rightarrow \mathrm{NaCl}(\mathrm{s})+\mathrm{HONO}(\mathrm{g})$

HONO is produced by passing a flow of humidified $\mathrm{HCl}_{(\mathrm{g})}$ over a $\mathrm{NaNO}_{2(s)}$ bed, resulting in the near $100 \%$ production of $\mathrm{HONO}$ from the $\mathrm{HCl}$ via reaction (R2). Since the production of HONO proceeds only in the presence of water vapour (Febo et al., 1995), the generation system needs to be maintained at a constant relative humidity $(\mathrm{RH})$. The relative humidity is the most critical factor controlling the stability of the HONO generation system, since at high humidity, deliquescence is a problem. In order to prevent saturation of the nitrite bed, the HONO generation system was temperature-controlled using a thermostat bath to approximately $35^{\circ} \mathrm{C}$, since it was known that the room temperature would not exceed this temperature.

For the typical operating conditions used, the average RH of the HONO generation system was $(61.6 \pm 7.6) \%$ over the measurement period. In this range of $\mathrm{RH}$, deliquescence was not observed, ensuring a highly stable HONO output source. 
Recent studies on HONO dissociation have found that the main dissociation reaction is best described as:

$\mathrm{HONO}_{\text {gas }}+\mathrm{HONO}_{\text {ads }} \longrightarrow \mathrm{NO}+\mathrm{NO}_{2}+\mathrm{H}_{2} \mathrm{O}$

where $\mathrm{HONO}_{\mathrm{ads}}$ is the surface concentration of HONO that stays adsorbed on the nitrite powder (Febo et al., 1995). To reduce the dissociation processes, it is critical to keep the product $\left(\mathrm{HONO}_{\text {gas }} \times \mathrm{HONO}_{\text {ads }}\right)$ inside the reaction bed as low as possible. It is thought that continuous mixing of the nitrite powder in the bed, or flowing air over the nitrite bed, as done here, prevents the formation of pockets in which very high HONO concentration levels can be reached, thus decreasing the amount of $\mathrm{HONO}_{\mathrm{ads}}$, and ensuring a highly pure output source (Febo et al., 1995).

The generated nitrous acid was quantified by collecting it into a $\mathrm{pH} 8.5 \mathrm{NaOH}$ solution, followed by subsequent analysis of the nitrite and chloride contents by Ion Chromatography (IC) (Dionex, DX-100 Ion Chromatograph; $4 \times 250 \mathrm{~mm}$ analytical ion-exchange column). Typical operating conditions included: sparging gas: UHP Helium; eluent: 1.8-mM $\mathrm{Na}_{2} \mathrm{CO}_{3} / 1.7-\mathrm{mM} \mathrm{NaHCO} 3$; eluent flow rate: $1.95 \mathrm{~mL} / \mathrm{min}$; injection volume: $25 \mu \mathrm{L}$.

During the measurement period, the HONO generation system produced on average a HONO mixing ratio of $(9.76 \pm 0.11)$ ppmv, equivalent to a generation rate of (122.4 \pm 1.4$)$ $\mathrm{ng} / \mathrm{min}$. The stability of the HONO generation system was excellent, with a deviation of $\sim 1 \%$ over several months. A high HONO mixing ratio was needed for a stoichiometric yield of 2 during photolysis, however, this required subsequent dilution with zero air down to tens of ppbv levels, so as to be within the linear range of the detector.

In order to quantify the conversion efficiency of the HONO generation system, the certified hydrogen chloride gas standard required calibration. The hydrogen chloride was quantified by collecting it into $10-\mathrm{mL}$ vials containing $\mathrm{pH} 8.5 \mathrm{NaOH}$ solution, followed by subsequent analysis of the chloride by Ion Chromatography (IC). Typical operating conditions are identical to those utilized for the quantification of the HONO produced by the HONO generation system.

The HONO generation system was calibrated regularly, allowing calculation of the conversion efficiency:

$$
\text { Conversion efficiency }=\frac{[\mathrm{HONO}](\mathrm{ppmv})}{[\mathrm{HCl}](\mathrm{ppmv})} \times 100 \%
$$

As expected, the HONO produced over the measurement period was found to be highly pure with an average conversion efficiency of $98.2 \pm 1.1 \%$.

\subsection{Direct $j$ monitor}

\subsubsection{Theoretical considerations}

The effect of reactor geometry on the measured $j$ value has been previously studied by Zafonte et al. (1977). A spherical reactor of the type used by Sickles and Jeffries (1975) and a cylindrical (plug flow) reactor were examined (Zafonte et al., 1977). They found the $j$ value measured in the spherical cell to be flow dependent, yielding higher $j$ values at higher flow rates, while the $j$ values in the cylindrical cell were independent of flow rate. 
This flow dependence is attributed to the spherical (stirred flow) reactor requiring thorough mixing for maximum photolysis efficiency. Due to the undesirable flow dependence of the spherical reactor, the cylindrical (plug flow) reactor is the appropriate geometry for a HONO actinometer.

The calculation of the photodissociation constant of HONO is proportional to the fractional change in the input $\mathrm{HONO}$ mixing ratio $\left(\left[\mathrm{HONO}_{0}\right)\right.$ during its passage through our reactor, and $j_{\mathrm{HONO}}$ is calculated as

$$
\mathrm{j}_{\text {HONO }}=\frac{\Delta[\mathrm{HONO}]}{[\mathrm{HONO}]_{0}} \times \frac{f}{V} \times \frac{1}{\varphi} \times \frac{1}{T}
$$

where $\Delta[\mathrm{HONO}]$ is the measured decrease in the nitrous acid mixing ratio as a result of photolysis; $[\mathrm{HONO}]_{0}$ is the nitrous acid mixing ratio before photolysis; $f$ is the flow rate through the photolysis cell, $V$ is the photolyzed volume, $\varphi$ is the stoichiometric yield during photolysis, and $T$ is the overall transmission factor of the quartz tube for UV light (calculated in the following section). The calculation of the stoichometric yield during photolysis $(\varphi=2)$, is based on the chemistry of the reaction system and its validity is discussed in Section 2.3.4.

Consideration of the Fresnel equation causes concern over the most appropriate geometry to be used for the actinometer for the direct determination of $j$. For natural sunlight (unpolarized radiation) at a single interface, the Fresnel equation reduces to the following form (Zafonte et al., 1977):

$$
R=\frac{\sin ^{2}(i-\theta)}{2 \sin ^{2}(i+\theta)}+\frac{\tan ^{2}(i-\theta)}{2 \tan ^{2}(i+\theta)}
$$

where $R$ is the reflection coefficient for natural sunlight at the interface; $i$ is the angle of incident radiation on the surface; and $\theta$ is the angle of the refracted or transmitted radiation.

The intensity of reflected and refracted light rays from the air-quartz-air interface is given by the following:

$$
I_{\text {reflected }}=I_{0} \times \frac{2 R}{1+R}
$$

and

$$
I_{\text {refracted }}=I_{0} \times \frac{1-R}{1+R}=I_{1}
$$

where $I_{0}$ is the incident ray of light.

The contributions to the total light intensity within the actinometer are given by:

$$
I_{n+1}=I_{n} \times \frac{2 R}{1+R} \quad \text { for } \mathrm{n}>0
$$

The total light intensity can then be easily found:

$$
I_{\text {total }}=I_{1}+I_{2}+I_{3}+\cdots+I_{n}+\cdots
$$


The summation in (8) has a solution commonly encountered in physical problems, and it is found that $I_{\text {total }}=I_{0}$, so that $T=1$. Thus, no transmission correction factor need be applied when the reactor is infinite in length, or where there is no inlet/outlet system, since the internally reflected light ray will exactly compensate for the reflected light lost initially (Zafonte et al., 1977). An 'end correction' can be made for a finite tubular reactor, which is proportional to the area of the endcaps and inversely proportional to a function of photolysis cell length. This 'end correction' accounts for both the internally reflected light lost at the ends and the light not entering the reactor at the ends. Orientation of the tube in the NorthSouth direction resulted in an estimated maximum shading of the cell of $<1 \%$ during ambient measurements, so the end correction was considered negligible.

Dickerson and Stedman (1980) tested the validity of the calculations done by Zafonte $e$ al. (1977) by sliding one to three additional tubes over their photolysis tube, and measuring the $j$ value; within the precision of their experiment $( \pm 5 \%)$, the additional tubes had no effect on the measured $j$ value. Jackson et al. (1975) further verified the validity of the calculations by rotating the cell in a range of orientations and observing $<5 \%$ change in signal.

\subsubsection{Continuous j monitoring system}

A Heraeus Amersil Electrically Fused quartz (Chemglass, HSQ-300) cylindrical cell was selected for the photolysis cell in the continuous $j_{\text {HONO }}$ monitoring system. The HONO generation system flows through the $13.8 \pm 0.2 \mathrm{~cm}$ photolysis cell $(2.5 \mathrm{~cm}$ I.D.) at a flow rate of $30.4 \mathrm{~mL} / \mathrm{min}$, yielding a photolysis exposure time of approximately $2.2 \mathrm{~min}$. The ends are darkened so as to minimize reflections. Figure 1 shows the experimental system used for ambient photolysis measurements. This setup enabled sequential measurements of the input HONO sample and the photolyzed sample to be easily obtained.

The precision of the direct $j_{\mathrm{HONO}}$ monitor was examined in the laboratory using an incandescent light source that emits $\sim 10 \%$ of the full radiant power expected from natural sunlight at solar noon. Consecutive experiments showed a precision in the photolysis rate of better than $1 \%$. This gives an upper limit on the precision of the photolysis procedures and analytical technique used in this experiment. Therefore, fractional HONO losses of greater than $1 \%$ could be used to calculate $j_{\text {HONO }}$.

The photolysis cell was mounted on supports on the roof of a 3-story building at York University, approximately $1 \mathrm{~m}$ above the roof surface at ambient temperature. The roof surface

Fig. 1 A schematic diagram of the direct jHONO monitor used for ambient measurements.

photolyzed sample $\rightarrow$ input (unphotolyzed) HONO sample. Typical zero-air flow rate: 1.8 L/min

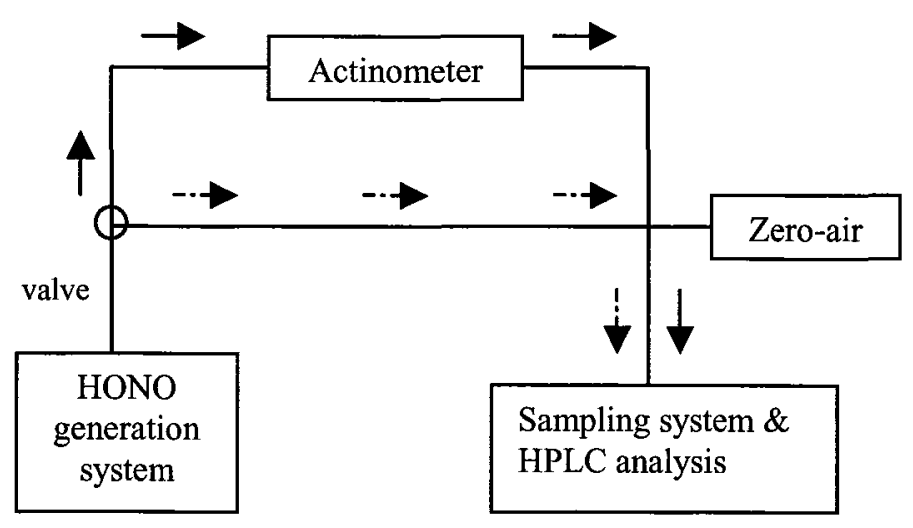


Table 1 Best-estimate systematic uncertainties in the parameters used in (3) to calculate measured $j$ HONO values

\begin{tabular}{lll}
\hline Parameter & Symbol & $\pm 1 \sigma(\%)$ \\
\hline HONO mixing ratio before photolysis & {$[\mathrm{HONO}]_{0}$} & 0.25 \\
Change in mixing ratio due to photolysis & $\Delta[\mathrm{HONO}]$ & 0.50 \\
Flow rate through photolysis cell & $F$ & 1.3 \\
Photolyzed volume & $V$ & 1.5 \\
Stoichiometric yield during photolysis & $\Phi$ & $3^{\mathrm{b}}$ \\
Overall transmission factor of the quartz actinometer for UV light & $T$ & $1^{\mathrm{b}}$ \\
Total error & & $4^{\mathrm{a}}$ \\
& & $11^{\mathrm{b}}$ \\
\hline
\end{tabular}

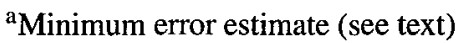

${ }^{\mathrm{b}}$ Maximum error estimate (see text)

was covered with black felt so that the actinometer could respond to all downwelling radiation while minimizing ground reflections. The axis of the photolysis tube was oriented in the North-South direction. The location of the assembly avoided direct shading from other objects at any time during measurements, and minimized reflected radiation from other structures. The actinometer assembly was connected by darkened Teflon tubing to the HONO measurement and generation systems located inside the building. The exterior of the photolysis cell was cleaned thoroughly with ethanol daily.

\subsubsection{Measurement error analysis and detection limit of actinometer}

The uncertainty on the measured $j_{\text {HONO values due to each of the parameters in (3) was }}$ examined (refer to Table 1 ). The best-estimate systematic uncertainty on [HONO $]_{0}$ was taken as the error in the chromatographic integration of the corresponding sample peak $( \pm 0.25 \%)$, as discussed in 2.1. Under the valid assumption that the chromatographic integration error was constant for all HONO mixing ratios encountered during ambient measurements, the error in $\left[\mathrm{HONO}_{0}\right.$ was simply doubled to obtain the uncertainty in the change in HONO mixing ratio due to photolysis. This results in a minimum detectable $j_{\mathrm{HONO}}$ value $\left(3 \sigma_{\Delta[\mathrm{HONO}]}\right)$ of 5.7 $\times 10^{-4} / \mathrm{sec}$ for our optically thin actinometer.

Error contributions of $\pm 1.3 \%$ and $\pm 1.5 \%$ were assigned to the parameters $f$ and $V$, respectively, based on the uncertainties in the total flow rate $(30.4 \pm 0.4 \mathrm{~mL} / \mathrm{min})$, and in the length of the actinometer $(13.8 \pm 0.2 \mathrm{~cm})$. A maximum uncertainty of $\pm 1 \%$ in the overall transmission factor of unity was estimated based on the maximum shading of the cell during ambient measurements due to the cell's orientation in the North-South direction, as discussed in 2.3.1. The best-estimate upper error limit on the stoichiometric yield during photolysis $( \pm 3 \%)$ was calculated as the percentage change in the HONO concentration at the end of the photolysis exposure time of $2.2 \mathrm{~min}$. (@ SZA $=0^{\circ}$ ), due to the inclusion of possible interfering reactions, in addition to the primary photodissociation process of HONO. For a detailed discussion of the kinetics of these reactions, refer to Section 2.3. 4.

Finally, we calculated the lower and upper error limits on the photodissociation constant of HONO, as shown in the last row of Table 1. Thus, the maximum error that we can expect in our measured $j_{\text {HONO }}$ values under clear sky conditions at sunrise $(5 \%$ photolysis; $\left.j=0.2 \times 10^{-3} / \mathrm{sec}\right)$ is $11 \%$, whereas at solar noon ( $40 \%$ photolysis; $j=1.5 \times$ 
$10^{-3} / \mathrm{sec}$ ), the estimated uncertainty is reduced to $4 \%$. The reasonably small error estimates on the measured $j_{\mathrm{HONO}}$ values thus provides confidence in the measured HONO photolysis rates, even during early morning when this photodissociation process is likely to be most important.

\subsubsection{Kinetics of HONO recombination and heterogenous HONO loss reactions}

When the photolysis cell is exposed to sunlight, the primary photodissociation process is:

(R1) $\mathrm{HONO}+h v \rightarrow \mathrm{OH}+\mathrm{NO} \quad j_{\mathrm{HONO}}=1.6 \times 10^{-3} / \mathrm{sec}$ (at $0^{\circ}$ zenith angle)

(Demerjian et al., 1980)

(R4) $\mathrm{OH}+\mathrm{HONO} \rightarrow \mathrm{NO}_{2}+\mathrm{H}_{2} \mathrm{O} \quad k_{l}=6.0 \times 10^{-12}\left(\mathrm{~cm}^{3} /\right.$ molecule sec $)$

(Atkinson et al., 2004)

The recombination reaction (R5) must be considered, since significant concentrations of NO and $\mathrm{NO}_{2}$ can be produced during HONO photolysis:

$$
\mathrm{NO}_{2}+\mathrm{NO}+\mathrm{H}_{2} \mathrm{O} \rightarrow 2 \mathrm{HONO} \quad k_{2}=4.41 \times 10^{-40}\left(\mathrm{~cm}^{6} / \text { molecule }^{2} \mathrm{sec}\right)
$$

(Kaiser and $\mathrm{Wu}, 1977$ )

Assuming steady state conditions for the hydroxyl radical, the HONO loss rate via (R1) and (R4) is

$$
\mathrm{HONO}_{\text {loss }}=2_{j_{\mathrm{HONO}}}[\mathrm{HONO}]
$$

while the HONO production rate via (R5) is

$$
\mathrm{HONO}_{\text {prod }}=2 k_{2}\left[\mathrm{NO}_{2}\right][\mathrm{NO}]\left[\mathrm{H}_{2} \mathrm{O}\right]
$$

During maximum solar daylight conditions, the maximum fractional loss of HONO is $40 \%$. This would result in a HONO concentration of $6 \mathrm{ppmv}$, and an $\mathrm{NO}$ and $\mathrm{NO}_{2}$ concentration of 2 ppmv. At a maximum relative humidity of $70 \%$, the production rate of HONO via (R5) would be $1 \times 10^{6}$ molecules $\mathrm{cm}^{-3} \mathrm{~s}^{-1}$, while the HONO loss rate via (R1) and (R4) would be $4.7 \times$ $10^{11}$ molecules $\mathrm{cm}^{-3} \mathrm{~s}^{-1}$. Since the HONO loss rate exceeds the HONO production rate via (R5) by 5 orders of magnitude, the HONO recombination reaction (R5) can be considered negligible at solar noon. At higher zenith angles, the HONO loss rate will be at most an order of magnitude less, but the recombination reaction (R5) can still be considered negligible.

The heterogeneous loss of $\mathrm{HONO}$ via its reaction with $\mathrm{HNO}_{3}$ must also be considered since the photolysis exposure time ( $2.2 \mathrm{~min}$.) may be long enough for significant concentrations of nitric acid to be formed:

$$
\mathrm{OH}+\mathrm{NO}_{2}+\mathrm{M} \rightarrow \mathrm{HNO}_{3}
$$

$$
k_{3}=3.3 \times 10^{-30}\left(\mathrm{~cm}^{6} / \text { molecule }^{2} \mathrm{sec}\right)
$$

(Atkinson et al., 2004) 


$$
\begin{aligned}
\mathrm{HONO}_{\text {ads }}+\mathrm{HNO}_{3, \mathrm{ads}} \rightarrow 2 \mathrm{NO}_{2}+\mathrm{H}_{2} \mathrm{O} & \begin{array}{l}
k_{4}=7 \times 10^{-19}\left(\mathrm{~cm}^{3} /\right. \text { molecule sec) } \\
\text { (Wallington and Japar, 1989) }
\end{array}
\end{aligned}
$$

The changes in the $\mathrm{OH}$ and $\mathrm{NO}_{2}$ mixing ratios with time at solar noon are,

$$
\begin{aligned}
& \frac{d[\mathrm{OH}]}{d t}=j_{\mathrm{HONO}}[\mathrm{HONO}]-[\mathrm{OH}]\left(k_{1}[\mathrm{HONO}]-k_{3}\left[\mathrm{NO}_{2}\right]\right) \\
& \frac{d\left[\mathrm{NO}_{2}\right]}{d t}=[\mathrm{OH}]\left(k_{1}[\mathrm{HONO}]-k_{3}\left[\mathrm{NO}_{2}\right]\right)
\end{aligned}
$$

so that the maximum $\mathrm{OH}$ and $\mathrm{NO}_{2}$ concentrations produced at the end of the photolysis time of $2.2 \mathrm{~min}$. via the above reaction sequence are $8.1 \mathrm{pptv}$ and $1.3 \mathrm{ppmv}$, respectively.

The $\mathrm{HNO}_{3}$ production rate via (R6) is:

$$
\mathrm{HNO}_{3, \text { prod }}=k_{3}[\mathrm{OH}]\left[\mathrm{NO}_{2}\right][\mathrm{M}] \text {, }
$$

resulting in a maximum $\mathrm{HNO}_{3}$ mixing ratio of $0.23 \mathrm{ppmv}$ at the end of the photolysis exposure time.

Assuming that all of the nitric acid produced via (R6) adheres to the walls of the photolysis cell, the heterogeneous loss rate of HONO (at a relative humidity of 70\%) in the photolysis cell due to its heterogeneous reaction with $\mathrm{HNO}_{3}(\mathrm{R} 7)$ will have an upper limit of:

$$
\mathrm{HONO}_{\text {heter.loss }}=k_{4}[\mathrm{HONO}]\left[\mathrm{HNO}_{3}\right]
$$

yielding $6.5 \times 10^{8} \mathrm{molecules} / \mathrm{cm}^{3} / \mathrm{sec}$. For the same initial HONO mixing ratio (10 ppmv), the HONO loss rate via (R1) and (R4) would be $4.7 \times 10^{11}$ molecules $\mathrm{cm}^{-3} \mathrm{~s}^{-1}$. Since the HONO loss rate due to (R1) and (R4) exceeds the upper limit of the heterogeneous HONO loss rate via (R7) by 3 orders of magnitude, the heterogeneous reaction of HONO with $\mathrm{HNO}_{3}$ can be considered negligible at solar noon. At higher zenith angles, the heterogeneous HONO loss rate will be at most an order of magnitude less, so that (R7) can still be considered negligible.

The additional possible loss of HONO due to surface effects needs to be considered. The reaction of $\mathrm{HONO}_{(g)}$ with $\mathrm{HONO}_{(\text {ads) }}$ (R3) (Febo et al., 1995), may be one such surface effect. By exposing the quartz cell to a compact fluorescent radiation source with negligible radiant power in the wavelength region of interest for HONO photolysis, it was possible to determine if surface effects were significant. The resultant measured loss of HONO from this test was less than the precision on the input HONO sample $(\sim 0.25 \%)$, indicating that surface effects could be neglected.

The quantum yield of unity for the photolysis of nitrous acid, $\Phi_{\text {photolysis }}$ as recommended by DeMore et al. (1997) is based on value given by Cox and Derwent (1976/1977) of $0.92 \pm 0.16$ at the prominent $365 \pm 5 \mathrm{~nm}$ band. The assumption that $\Phi_{\text {photolysis }}$ is unity over the entire wavelength region of interest is justified when the systematic error is neglected, since sufficient dissociation energy exists even at $390 \mathrm{~nm}$ to dissociate the HONO molecule. It is thus valid to use the stoichiometric yield, $\varphi=1+\Phi_{\text {photolysis }}=2$ during photolysis for all conditions encountered. 


\section{Results and discussion}

\subsection{Radiative transfer model}

The radiative transfer (RT) model used for intercomparison herein is the ACD Version 4.1 of the Tropospheric Ultraviolet Visible (TUV) code developed by Madronich (http://www.acd.ucar.edu/Science/Models/TUV/Interactive_TUV/). The results were calculated for clear sky conditions only.

A four-stream discrete ordinates code (DISORT) (Stamnes et al., 1988) with a pseudospherical approximation (Zeng et al., 1996) was used to calculate the atmospheric propagation. The pseudospherical approximation includes the sphericity of the Earth's atmosphere in order to calculate the attenuation of the direct beam and primary scattering (DeLuisi and Mateer, 1971; Dahlback and Stamnes, 1991). The plane parallel approximation, on the other hand, calculates higher-order (multiple) scattering, and thus, is expected to be less accurate than the pseudospherical method. The pseudospherical approximation, however, may be less accurate at high zenith angles due to its approximate treatment of multiple scattering.

Vertical profiles of air, ozone, and temperature are taken from the US Standard Atmosphere (USSA) (1976). The modeled and measured profiles used for atmospheric composition were scaled according to the observed $\mathrm{O}_{3}$ amount (data taken from the Total Ozone Mapping Spectrometer (TOMS) ozone processing team, NASA/GSFC Code 613.3 (http://toms/gsfc.nasa.gov/teacher/ozone_overhead_v8.html). Absorption by atmospheric ozone and $\mathrm{NO}_{2}$ were included in the calculations. Ozone cross sections are taken from Molina and Molina (1986) for $\lambda<350 \mathrm{~nm}$, and from World Meteorological Organization (WMO) (1985) for larger wavelengths. The cross sections for $\mathrm{NO}_{2}$ were taken from DeMore et al. (1994).

Although an average representation of atmospheric aerosols is hard to determine, aerosol scattering and absorption is important (Fiocco et al., 1978), and thus was accounted for in the model calculations. Scattering by aerosols is calculated using the Henyey and Greenstein (1941) phase function. The aerosol single scattering albedo and the asymmetry parameter were chosen from precalculated values. The typical continental aerosol profile by Elterman (1968) corresponding to $25 \mathrm{~km}$ visible range at ground level (scaled at other wavelengths with $\lambda^{-1}$ ) was used. Rayleigh scattering was also included in the computations, using the cross section parameterization by Nicolet (1984). For our model input parameters (see Table II), this resulted in an aerosol optical depth of 0.367 at $340 \mathrm{~nm}$. The average measured AOD of $(0.396 \pm 0.0426)$ at $340 \mathrm{~nm}$ is in good agreement with the model input value for June $21 \mathrm{st}, 2005$ (Data courtesy of AERONET for the nearest measurement site, Egbert $\left(44.226^{\circ} \mathrm{N}\right.$, $\left.79.750^{\circ} \mathrm{W}\right)$.

Exterrestrial (ET) solar flux data were taken from ATLAS-3 Solar Ultraviolet Spectral Irradiance Monitor (SUSIM) (1994) for $\lambda<400 \mathrm{~nm}$. Since the ET flux data applies specifically to the mean Earth-sun distance, which occurs in early April and October, and may change by as much as $\pm 3.4 \%$ at other times during the year (Demerjian et al., 1980), all actinic fluxes used were multiplied by the correction factor, $c_{f}=0.967$. These corrected actinic fluxes allow direct comparison to the clear sky experimental values obtained on June 21st, 2005.

The quantum yield, $\Phi_{\text {photolysis }}$ for the photodissociation of HONO was taken to be unity (Demore et al., 1997) and the absorption cross-section data was taken from Bongartz et al. (1991, 1994).

Table 2 contains a list of the user-selected parameters employed in the ACD TUV version 4.1 model calculations. For the centre of each wavelength interval in Table 2 of Madronich and 


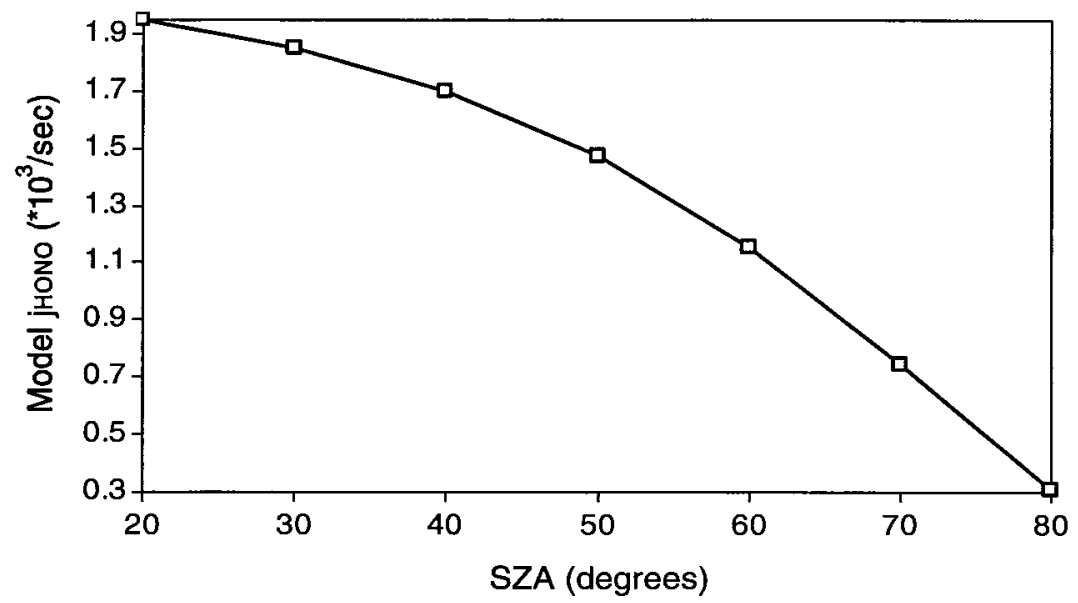

Fig. 2 Theoretical $j_{\mathrm{HONO}}$ values (ACD TUV version 4.1) for model input parameters in Table 2 and SZA $\leq$ $80^{\circ}$

Flocke (1998), the RT equation was carried out. The calculated $j_{\text {HONO }}$ values are displayed in Figure 2 as a function of zenith angle.

3.2. Comparison of clear-sky $\mathrm{j}_{\text {HONO }}$ values by chemical actinometry with RT model calculations

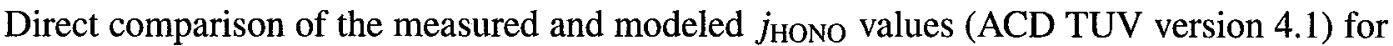
cloudless conditions on June 21st, 2005 at the measurement site is shown in Figure 3. On this date, ideal sky conditions prevailed with the sky being mainly clear throughout the day. The HONO photodissociation constant was measured from sunrise to mid-afternoon and the $j$ values were averaged for SZA intervals of $10^{\circ}$. For consistency, Eastern Standard Time (EST), rather than Eastern Daylight Time (EDT) was used when calculating solar zenith angles, resulting in the solar maximum near noon.

Since SZA of 0 and 10 degrees do not occur at the measurement site, RT model values and experimental values were only compared for $\mathrm{SZA} \geq 20^{\circ}$. Zenith angles larger than $80^{\circ}$ were excluded in the comparison since large errors can be expected in the corresponding

Table 2 List of the input parameters used in the ACD TUV version 4.1 model calculations of jHONO for June 21st, 2005

\begin{tabular}{ll}
\hline RT model input parameter & Value \\
\hline Wavelength-independent surface albedo & $5 \%$ \\
Measurement altitude & $0.089 \mathrm{~km}$ \\
Surface air pressure & $1006.24 \mathrm{mbar}$ \\
Surface air column & $2.133 \times 10^{25}$ molecules $/ \mathrm{cm}^{2}$ \\
Ozone column & $330.0 \mathrm{DU}^{\mathrm{a}}$ \\
SZA & Ranges from $20^{\circ}-80^{\circ}$ \\
Extraterrestrial (ET) solar flux correction factor & 0.967 \\
Total aerosol optical depth (AOD) @ 340 nm & 0.367 \\
\hline
\end{tabular}

${ }^{a} \mathrm{~A}$ constant value for the entire day was assumed. 


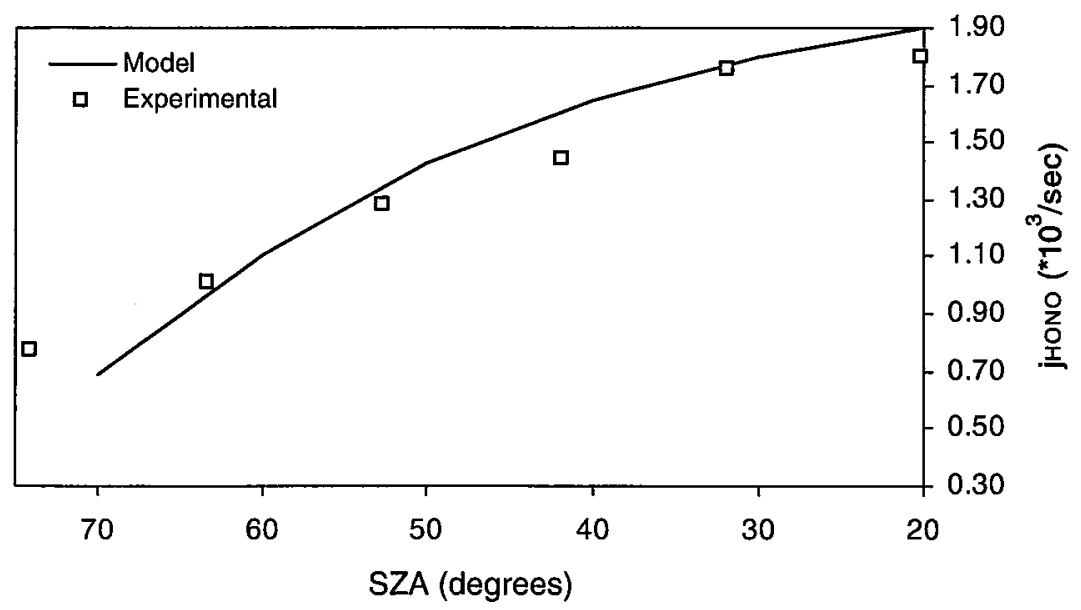

Fig. 3 Comparison between theoretical and measured $j_{\text {HONO }}$ values $\left(\times 10^{3} / \mathrm{sec}\right)$ for cloudless sky conditions and $\mathrm{SZA} \leq 75^{\circ}$

calculated $j$ values. This is due to the small actinic flux being largely composed of multiply scattered radiation (Demerjian et al., 1980).

As seen in Figure 3, there is better than $10 \%$ agreement between our measured $j$ values and those calculated using the ACD TUV model, with a slightly larger deviation for SZA > $65^{\circ}$. The error in the theoretical $j$ value is dictated primarily by the uncertainties introduced in the model input parameters such as the ET solar flux data and the absorption cross sections of ozone, as well as the uncertainties in the molecular photodissociation parameters, $\sigma(\lambda)$ and $\Phi(\lambda)$. These combined uncertainties can exceed more than $20 \%$. It is expected then that a larger SZA, small percentage errors in the atmospheric constituents will result in larger percentage errors in the calculated $j$ values. The error in the $j_{\text {HONO }}$ measurements is also expected to be higher at larger SZA due to the less ideal angular response of chemical actinometers at larger SZA. Thus, one must not be too critical when comparing theoretical and experimental photodissociation constants at $\mathrm{SZA}>65^{\circ}$.

The dependence of the measured $j_{\text {HONO }}$ values on the solar zenith angle was investigated for cloudless sky conditions on June 21st, 2005. The data was fit to the function cos (SZA) (see Figure 4 ), since this is a simple function that exhibits the necessary maximum in $j_{\mathrm{HONO}}$ at solar noon. The linearity for the angular dependence of $j_{\mathrm{HONO}}$ for zenith angles between $20^{\circ}$ and $65^{\circ}$ was excellent, with an $R^{2}>0.93$. The result of the least squares fit to the fitting function $\cos (\mathrm{SZA})$ for zenith angles between $20^{\circ}$ and $65^{\circ}$ and clear sky conditions is given as:

$$
\text { jHONO }=(2.102 \pm 0.144) x
$$

where $x$ is the cosine of the SZA in radians. This is in excellent agreement with the angular dependence of the modeled $j_{\text {HONO }}$ values (ACD TUV model version 4.1) for cloudless skies which has a $4.5 \%$ higher slope, and an $R^{2}>0.95$ (refer to Figure 4 ).

Our empirical angular dependence of $j_{\mathrm{HONO}}$ at the measurement site (15) during summertime clear-sky conditions is of use for the evaluation of the suppression and/or enhancement of the HONO photodissociation rate constant due to the presence of clouds, as discussed in detail in Section 3.4. 


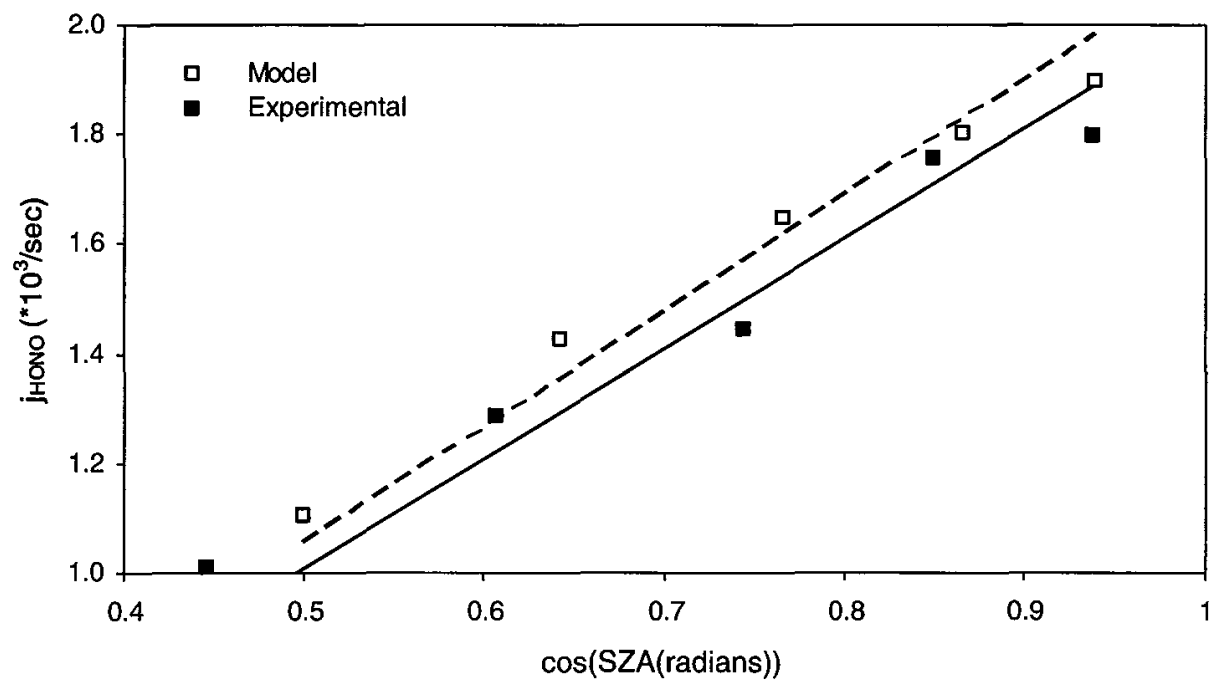

Fig. 4 Comparison between angular dependence of theoretical and measured $j_{\text {HONO }}$ during clear sky conditions and for $\mathrm{SZA} \leq 65^{\circ}$. _ model, - experimental

\subsection{Assessment of the integrated absorption cross section for gas-phase HONO}

\subsubsection{Absorption cross section data}

Accurate absorption cross sections and a well-resolved UV spectrum are required for the quantitative determination of gas-phase HONO by Differential Optical Absorption Spectroscopy (DOAS). In DOAS, the differential absorption spectrum is analyzed based on Lambert-Beer's law in order to determine the concentration, $c$, of the trace atmospheric species:

$$
c=\left(\frac{\log \left(\frac{I_{o}^{\prime}(\lambda)}{I(\lambda)}\right)}{\sigma^{\prime}(\lambda) L}\right)=\frac{D^{\prime}}{\sigma^{\prime}(\lambda) L}
$$

where $\sigma^{\prime}(\lambda)$ is the differential absorption cross section at wavelength $\lambda ; I_{o}^{\prime}(\lambda)$ is the initial differential intensity emitted by a suitable radiation source; $I(\lambda)$ is the radiation intensity after passing through a layer column density of the trace atmospheric species; $D^{\prime}$ is the differential optical density of a layer of species; $L$ is the total length of the light path; and $c$ is the concentration of the trace atmospheric species of interest (Platt, 1999). It is thus evident that any inaccuracy in the absorption cross section of HONO results in a direct systematic error in the concentrations measured by DOAS.

Previous analysis of the HONO infrared spectrum (Jones et al., 1951; d'Or and Tarte, 1951) has shown that gas-phase nitrous acid consists of a mixture of two planar isomeric forms in the ground electronic state. The trans rotamer is $404-531 \mathrm{cal} / \mathrm{mol}$ (Jones et al., 1951; McGraw et al., 1966; Varma and Curl, 1976) lower in energy than the cis rotamer, with a barrier to rotation from trans to cis on the order of $9.7 \mathrm{kcal} / \mathrm{mol}$ (Hall and Pimentel, 1963; Darsey and Thompson, 1987). The cross sections are always related to the sum of the trans- and cis-HONO concentration due to the large degree of uncertainty on the equilibrium constant (Becker et al., 1995), $K=p_{\text {trans }} / p_{\text {cis }}=3.25 \pm 0.30$ at $277 \mathrm{~K}$ (Bongartz et al., 1991). 
Several HONO absorption cross section data exist in the literature (Johnston and Graham, 1974; Cox and Derwent, 1976, 1977; Stockwell and Calvert, 1978; Perner and Platt, 1979; Vasudev, 1990; Bongartz et al., 1991, 1994; Febo et al., 1995; Pagsberg et al., 1997; Brust et al., 2000; Stutz et al., 2000), as compared in Table 3. The published data differs significantly, with spectral resolutions in the range of $<0.1-1 \mathrm{~nm}$, and various methods of HONO production (refer to Table 3 ). The production of high purity gas-phase nitrous acid with good temporal stability is critical for accurate HONO absorption cross section data, since it is difficult to determine the exact $\mathrm{HONO}$ concentration due to co-absorption of interfering nitrogen compounds $\left(\mathrm{NO}_{2}, \mathrm{~N}_{2} \mathrm{O}_{3}\right.$, and $\left.\mathrm{N}_{2} \mathrm{O}_{4}\right)$.

Bongartz et al. (1994) and Heland et al. (2001) have reported systematically lower concentrations of HONO measured by DOAS when performing intercomparison measurements with ion chromatography and the Long Path Absorption Photometer (LOPAP) instrument (Heland et al., 2001), respectively. These discrepancies prompted us to re-evaluate the integrated absorption cross-section for HONO in the 300-400 nm wavelength region.

\subsubsection{Oscillator strength of band system}

The near-ultraviolet absorption of nitrous acid has been assigned to an $\pi^{*} \rightarrow n_{o}$ transition (Sidman, 1958), localized on the $\mathrm{N}=\mathrm{O}$ bond, which is forbidden by the local symmetry of the nitro group. The $n_{o} \pi^{*}$ absorption of nitrous acid is well separated from other electronic transitions of the same molecule, which begin to absorb strongly below $270 \mathrm{~nm}$ (Cox et al., $1976,1977)$. Thus, the oscillator strength, $f$ of the entire band system $(300-400 \mathrm{~nm})$, is calculated as a measure of the optical absorption strength as:

$$
f=\frac{4 \varepsilon_{o} m c^{2}}{e^{2}} \int \frac{\sigma}{\lambda^{2}} d \lambda
$$

where $\epsilon_{o}$ is the permittivity of vacuum; $m$ and $e$ are the mass and charge of an electron, respectively; and $c$ is the speed of light (Steinfeld, 1974; Thorne, 1988). It is important to note that the oscillator strength is independent of the spectral resolution employed.

The measured photolysis rate constant, $j_{\mathrm{HONO}}$, along with spectral actinic fluxes, may be utilized to determine the integrated product of the molecular photodissociation parameters $\sigma(\lambda)$ and $\Phi(\lambda)$ for HONO:

$$
\int_{300 \mathrm{~nm}}^{400 \mathrm{~nm}} \sigma(\lambda) \varphi(\lambda) d \lambda=\frac{j_{\mathrm{HONO}}(\mathrm{SZA}, h)}{\int_{300 \mathrm{~nm}}^{400 \mathrm{~nm}} F(\lambda, \mathrm{SZA}, h) d \lambda}
$$

where $\int_{300 \mathrm{~nm}}^{400 \mathrm{~nm}} \sigma(\lambda) \varphi(\lambda) d \lambda$ and $\int_{300 \mathrm{~nm}}^{400 \mathrm{~nm}} F(\lambda$, SZA, $h) d \lambda$ are the integrated product of absorption cross section/quantum yield, and the integrated spectral actinic flux (at zenith angle SZA and altitude $h$ ), respectively, over the wavelength range 300-400 $\mathrm{nm}$ centred about $\lambda$; and $j_{\mathrm{HONO}}(\mathrm{SZA}, h)$ is the measured photolytic rate constant for HONO (at zenith angle SZA and altitude $h$ ).

Since the quantum yield for HONO photodissociation is unity over the entire wavelength region of interest (DeMore et al., 1997; Cox et al., 1976, 1977), (18) simplifies to

$$
\int_{300 \mathrm{~nm}}^{400 \mathrm{~nm}} \sigma(\lambda) d \lambda=\frac{\mathrm{j}_{\mathrm{HONO}}(\mathrm{SZA}, h)}{\int_{300 \mathrm{~nm}}^{400 \mathrm{~nm}} F(\lambda, \mathrm{SZA}, h) d \lambda}
$$


Table 3 Comparison of the absolute HONO absorption cross sections at $354 \mathrm{~nm}$

\begin{tabular}{|c|c|c|c|}
\hline Reference & Spectral resolution (nm) & $\sigma$ at $354 \mathrm{~nm}\left(\times 10^{20} \mathrm{~cm}^{2}\right)$ & HONO production \\
\hline Johnston and Graham (1974) & 0.87 & $13.6 \pm 2.7$ & $\mathrm{NO}+\mathrm{NO}_{2}+\mathrm{H}_{2} \mathrm{O} \rightleftharpoons 2 \mathrm{HONO}$ \\
\hline Cox and Derwent $(1976,1977)$ & $<0.1$ & $67 \pm 7$ & $\mathrm{H}_{2} \mathrm{SO}_{4}+\mathrm{NaNO}_{2}=\mathrm{H}_{2} \mathrm{O} \rightarrow \mathrm{HONO}+$ products \\
\hline Stockwell and Calvert (1978) & $<1$ & $49.6 \pm 4.9$ & $\mathrm{NO}+\mathrm{NO}_{2}+\mathrm{H}_{2} \mathrm{O} \rightleftharpoons 2 \mathrm{HONO}$ \\
\hline Perner and Platt (1979) & 0.6 & a & $?$ \\
\hline Vasudev (1990) & $?$ & $49.6 \pm 4.9$ & $\mathrm{NO}+\mathrm{NO}_{2}+\mathrm{H}_{2} \mathrm{O} \rightleftharpoons 2 \mathrm{HONO}$ \\
\hline Bongartz et al. $(1991,1994)$ & 0.1 & $(54.9)^{\mathrm{b}} 46.9 \pm 2$ & $\mathrm{H}_{2} \mathrm{SO}_{4}+\mathrm{NaNO}_{2}+\mathrm{H}_{2} \mathrm{O} \rightarrow \mathrm{HONO}+$ products \\
\hline Febo et al. (1995) & 1 & - & Continuous HONO source ${ }^{c}$ \\
\hline Pagsberg et al. (1997) & 0.4 & $50.2 \pm 5$ & $\mathrm{~F}+\mathrm{H}_{2} \mathrm{O} \rightarrow \mathrm{HF}+\mathrm{OH}, \mathrm{OH}+\mathrm{NO} \rightarrow \mathrm{HONO}$ \\
\hline Brust et al. (2000) & 0.5 & $38.9 \pm 6$ & Continuous HONO source ${ }^{c}$ \\
\hline Stutz et al. (2000) & 0.08 & $51.9 \pm 0.3$ & Continuous HONO source ${ }^{\mathfrak{c}}$ \\
\hline
\end{tabular}

${ }^{a}$ Only $\sigma^{\prime}$ is given

${ }^{b}$ Value reported in 1991 corrected in 1994 by a factor of 0.855

${ }^{\mathrm{c}}$ Refer to Febo et al. (1995) for details 
so that substitution into (17) yields

$$
f=\frac{4 \varepsilon_{o} m c^{2} j_{\mathrm{HONO}}(\mathrm{SZA}, h)}{e^{2}} \int_{300 \mathrm{~nm}}^{400 \mathrm{~nm}} \frac{1}{\lambda^{2} \bullet F(\lambda, \mathrm{SZA}, h) d \lambda}
$$

Calculation of the integrated absorption cross section by (20) should result in a more reliable measure of the optical absorption strength of gas-phase nitrous acid since it eliminates the usual major reservations associated with the available experimental HONO spectral data: (1) undercorrection/overcorrection of $\sigma(\lambda)$ due to co-absorption of $\mathrm{NO}_{2}, \mathrm{~N}_{2} \mathrm{O}_{4}$, and $\mathrm{N}_{2} \mathrm{O}_{3}$; and (2) the stability and purity of the gas-phase nitrous acid source.

The oscillator strength of gas-phase nitrous acid was calculated for clear-sky conditions at a solar zenith angle of $20.2^{\circ}$, ozone column 330 Dobson units, using modeled spectral actinic fluxes (ACD TUV model version 4.1) and our ambient $j_{\text {HONO }}$ data. The modeled spectral actinic fluxes have a spectral resolution of $1 \mathrm{~nm}$ for $\lambda \leq 315 \mathrm{~nm}$, and $5 \mathrm{~nm}$ resolution for $315<\lambda<400 \mathrm{~nm}$, as prescribed by the ET flux data. For the entire band system of HONO (300-400 nm), we obtain an oscillator strength of $1.06 \times 10^{-3}$. During the recent International Photolysis Frequency Measurement and Model Intercomparison (IPMMI), Bais et al. (2003) found that at local noon and for $\lambda>315 \mathrm{~nm}$, the average deviation for the ACD TUV model (version 4.0) from spectral actinic flux measurements is within $1 \%$. Adopting this error estimate for the latest model version, along with the 4\% error estimate on $j_{\text {HONO }}$ for clear skies at solar noon (refer to Section 2.3.3), yields a total uncertainty estimate of $\pm 4.1 \%$ on our oscillator strength, so that $f=(1.06 \pm 0.044) \times 10^{-3}$.

Systematically low measurements of the concentration, $c$ of a trace atmospheric species by DOAS is consistent with an underestimate in the differential absorption cross section, as inferred from (16). Thus, the $(13 \pm 5) \%$ lower HONO mixing ratios measured by DOAS (Kleffmann et al., 2002) when compared to LOPAP (Heland et al., 2001), suggest that the recent differential absorption cross section data for HONO (Bongartz et al., 1991, 1994; Brust et al., 2000; Stutz et al., 2000) is (13 \pm 5$) \%$ too low. Our integrated oscillator strength for gas-phase HONO is an average $19.1 \%$ larger than the value reported by Bongartz et al. (1991, 1994), whose absorption cross section data agree to within $5 \%$ of the most recent data by Stutz et al. (2000). The lower limit estimate of our oscillator strength $(f=1.016$ $\left.\times 10^{-3}\right)$ is a factor of $(1.145 \pm 0.045)$ times larger than the integrated value reported by Bongartz et al. (1991), in excellent agreement with the weighted mean of the ratio [HONO, LOPAP]/[HONO, DOAS] of $(1.13 \pm 0.05)$ (Heland et al., 2001). This, however, does not suggest that our lower estimate of $f$ is more reliable, since the error on the weighted mean of the ratio [HONO, LOPAP]/[HONO, DOAS] represents $3 \sigma$, and reflects the statistical precision only (Heland $e t$ al., 2001). It is therefore evident that further experimental work is necessary for more reliable HONO absorption cross section data, and ultimately, more accurate measurements of HONO by DOAS.

\subsection{In-cloud measurements of $J_{\mathrm{HONO}}$}

\subsubsection{Measurement of the effect of clouds on the measured $J_{\mathrm{HONO}}$}

The effect of clouds on the amount of radiation available for the photodissociation of HONO was examined at the measurement site. The HONO photolysis rate was measured during cloudy conditions on 5 occasions for the period of May-July 2005. The measured cloud covers observed in Toronto for the measurement dates are displayed in Table IV. Cloud 
Table 4 Measured cloud cover for the Toronto Pearson International Airport site $\left(43^{\circ} 40^{\prime}\right.$ $\mathrm{N}, 79^{\circ} 36^{\prime} \mathrm{W}$ at $173.40 \mathrm{~m}$ ) during the measurement period of May 27 - July 12 th, 2005 inclusive. Data provided by Environment Canada

\begin{tabular}{ll}
\hline Measurement date & Measured cloud cover \\
\hline May 27 & $5 / 10-9 / 10$ \\
June 1 & $1 / 10-4 / 10$ \\
June 7 & $5 / 10-9 / 10$ (morning) \\
& $1 / 10-4 / 10$ (afternoon) \\
June 8 & $1 / 10-4 / 10(\text { during } 10: 00-15: 00)^{\mathrm{a}}$ \\
July 12 & $5 / 10-9 / 10$ \\
\hline
\end{tabular}

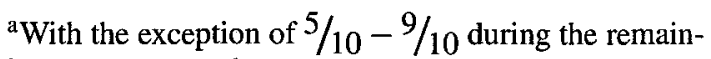
ing measurement hours.

covers in the range of 1-4 tenths indicate partly cloudy conditions, while cloud covers of 5-9 tenths, and 10 tenths are representative of mostly cloudy and overcast sky conditions, respectively.

Figure 5 displays the measured $j$ value $\left(j_{\text {cloudy }}\right)$ as well as the interpolated $j_{\text {clear-sky }}$ value (calculated using (15)) based on the measured data in Figure 3, for direct comparison. For conditions of scattered cloud, enhancement and suppression of the $j$ values occurs, as expected from theory (Madronich, 1987). As a result of the sun shining directly between brightly illuminated clouds, or the presence of bright thin cloud cover, enhancement occurs. Thin cloud cover causes enhancement exclusively due to the isotropic $2 \cos \theta_{o}$ (where $\theta_{o}=$ SZA) contribution from partially diffused light. Suppression occurs when the direct sun is obscured by a thicker cloud (Madronich, 1987).

It is possible to estimate the below-cloud actinic flux by simply multiplying the clear-sky actinic flux by a single transmissivity coefficient (Atwater and Brown, 1974), which we will denote as $\tau$. Cloud transmissivities have been previously determined as a function of SZA for representative cloud types, thicknesses, and densities (Haurwitz, 1948). The coefficient $\tau$ should be calculated as a function of the actinic flux, denoted $\tau_{\text {actinic }}$, rather than the irradiance $\left(\tau_{\text {irradiance }}\right)$, since the irradiance expresses the flow of energy through horizontal surfaces. However, since irradiance is easier to measure than actinic flux, $\tau_{\text {irradiance }}$ is often used instead. Besides the fact that below-cloud and in-cloud actinic fluxes are not equal (Madronich, 1987), $\tau_{\text {actinic }}$ needs to be used with caution since the actual actinic flux will vary significantly during conditions of partial cloud cover (Demerjian et al., 1980).

The transmissivity coefficient, $\tau$ (as a function of actinic flux) was estimated for our cloudy data by evaluating the ratio $\left(j_{\text {cloudy }} / j_{\text {clear-sky }}\right)$. The resultant values are shown in Figure 6 as a function of SZA for all below-cloud data. Enhancement and suppression occurred both at low and high SZA. The extent to which the photolysis frequency was enhanced and/or suppressed due to cloud conditions depended upon the optical thickness of the clouds and the measured cloud cover at the measurement site. Compared to a cloudless atmosphere, the optically thick cloud conditions on May 27th suppressed the $j$ values at all zenith angles encountered by as much as $67 \%$. This compares well with measurements by Kylling et al. (2005) who report suppression of the actinic flux during thick cloud conditions of about 55-65\%. On June 1st, 7th and 8th, similar cloud conditions were observed at the measurement site. The optical thickness of the clouds varied, with optically thinner clouds present at high zenith angles. The photodissociation constant was reduced by as much as $59 \%$ at lower zenith angles, and increased by as much as a factor of 1.7 at high zenith angles. Shetter and Müller (1999) have also reported photolysis frequency enhancements due to thin clouds of about a factor of 2 over cloudless values. Finally, on July 12th, optically thicker clouds were observed on the horizon, resulting in a maximum suppression of the actinic flux of $80 \%$ at higher zenith 


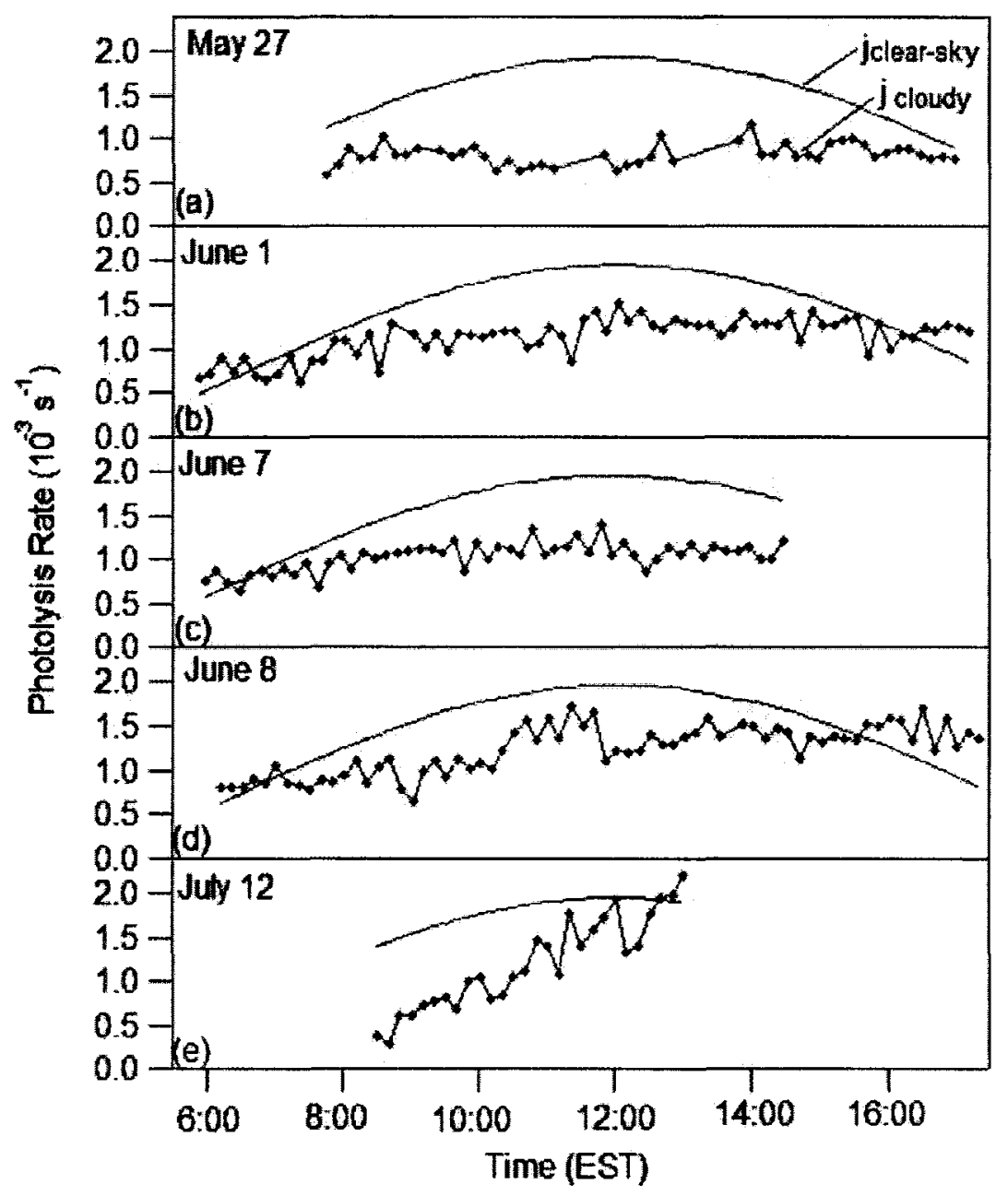

Fig. 5 Direct comparison of measured $j_{\text {cloudy }}$ data and interpolated $j_{\text {clear-sky }}$ data for several cloudy days during the measurement period at the site. (a) May 27. (b) June 1. (c) June 7. (d) June 8. (e) July 12.

angles. Near solar noon, the observed optical thickness of the clouds above the measurement site decreased considerably, and the photolysis frequency was enhanced by as much as $16 \%$. This compares well with that of Lantz et al. (1996) who reported a $24 \%$ enhancement in the actinic flux over clear sky values around local noon for cloud covers of $50 \%$ and a cloud optical depth of 4 .

\subsubsection{Comparison of measurements with $R T$ model calculations of $j_{\mathrm{HONO}}$ under cloudy conditions}

Actinic flux data generated by the ACD TUV model were calculated for cloudless sky conditions, since clouds are a challenge to treat realistically in RT model calculations. Due to the high variability of their vertical and horizontal extent, and the inhomogeneous distribution of the size and number of cloud particles, the characterization of real clouds proves difficult. The calculations are further complicated by the possible absorption of light by surrounding atmospheric gases and the cloud particles (Madronich, 1987). Approximating clouds as a single, homogeneous layer (1-D simulation) is the easiest approach when introducing clouds in a RT model. During conditions of broken cloud cover, however, 
this approximation is especially limited. In an attempt to investigate the 3-D effects of clouds, several recent model studies (Stephens et al., 1990; Chambers et al., 1997) have mainly examined the change in radiance and actinic flux values at fixed locations due to inhomogeneities. Although the 3-D effect of clouds on the actinic flux is solvable, the major challenge that one is faced with is the specification of cloud input (Kylling et al., 2005).

The actual in-cloud transmission factors, $\tau$ (based on actinic flux) have been previously calculated by Madronich (1987) as a complex function of SZA, diffuse versus direct incidence, ground albedo, absorption loss, and in-cloud altitude. As a typical summertime (low ground albedo) estimate of $\tau$, Madronich (1987) provides the following range of values: $\sim 0.4-1.7$. These calculations required using a more detailed radiative transfer model, the delta-Eddington method of Joseph et al. (1976). This method predicts transmissivity with an accuracy of a few percent or better for lower zenith angles and thick clouds, and thus, may underestimate enhancement particularly at high zenith angles. Assumptions of Madronich's (1987) calculations included a single, homogeneous cloud of infinite horizontal extent with definite vertical optical depth, and no scattering or absorption outside of the cloud. The cloud single scattering albedo, $\omega_{o}$ and the SZA were varied, for either purely collimated or purely diffuse incident light. The phase function asymmetry factor, g, was given the value 0.875 , a typical value for clouds (Joseph et al., 1976).

The values of $\tau$ calculated by Madronich (1987) are comparable to the measured values obtained herein (0.2-1.7) for the suppression and/or enhancement of $j$ due to clouds, however, they do not take into account the change in actinic flux due to cloud inhomogeneities.

\section{Conclusions}

The optically thin chemical actinometer described herein was used to measure the HONO photodissociation constant, $j_{\mathrm{HONO}}$ at an urban site in Toronto, Canada, during the period of May - July 2005. Measurements of $j_{\text {HONO }}$ were obtained for SZA ranging from $20-75^{\circ}$, and for different sky conditions. Maximum error estimates on $j_{\mathrm{HONO}}$ under clear skies range from $11 \%$ at sunrise, to $4 \%$ at solar noon, with a minimum detection limit of $5.7 \times 10^{-4} / \mathrm{sec}$ for our actinometer. The relatively small error estimates on the measured $j_{\mathrm{HONO}}$ values thus provides confidence in the measured HONO photolysis rates, even during early morning when this photodissociation process is likely to be most important. Experimental clear-sky values of $j_{\text {HONO }}$ were compared with radiative transfer model values (ACD TUV version 4.1) and were found to be within better than $10 \%$ agreement for SZA $<65^{\circ}$. For SZA $\geq 65^{\circ}$, the discrepancy between model and experiment is slightly larger as expected since greater inaccuracies in both theory and measurements are expected at higher solar zenith angles.

For conditions of scattered cloud, enhancement, and suppression of the $j_{\text {HONO }}$ values occurred, by as much as 16\%-70\% and 59\%-80\%, respectively. These values are in good agreement with literature (Lantz et al., 1996; Shetter et al., 1999; Kylling et al., 2005). For all below-cloud data, the experimental transmission factors, $\tau$, ranged from $0.2-1.7$ for SZA $\leq 65^{\circ}$. This is in good agreement with the typical summertime RT model estimate given by Madronich (1987) (0.4-1.7), however, does not take into account the change in actinic flux due to cloud inhomogeneities.

Recent reports of systematically low measurements of HONO mixing ratios by DOAS (Bongartz et al., 1994; Heland et al., 2001), consistent with an underestimate in the differential 
absorption cross section, prompted us to re-evaluate the integrated absorption cross-section for HONO in the 300-400 nm wavelength region. The integrated band area of the $n \pi^{*}$ transition for gas-phase nitrous acid yields an oscillator strength, $f=1.06 \pm 0.044) \times 10^{-3}$ based on our clear-sky data. This is $19.1 \%$ higher than the integrated value reported by Bongartz et al. $(1991,1994)$, whose absorption cross section data agree to within $5 \%$ of the most recent data by Stutz et al. (2000). Further experimental work is therefore necessary to obtain more reliable HONO absorption cross section data, and thus, more accurate measurements of HONO by DOAS.

\section{Acknowledgments}

This research was funded in part by NSERC. Thanks to the Department of Chemistry at York University for use of the equipment. We thank Norm O'Neill and Alain Royer for use of their data for the Egbert site, and an anonymous referee for helpful criticism of an earlier version of this paper.

\section{References}

Atkinson, R., Baulch, D.L., Cox, R.A., Crowley, J.N., Hampson, R.F., Hynes, R.G., Jenkin, M. E., Rossi, M.J., Troe, J.: Evaluated kinetic and photochemical data for atmospheric chemistry volume I - gas phase reactions of $\mathrm{O}_{x}, \mathrm{HO}_{x}, \mathrm{NO}_{x}$, and $\mathrm{SO}_{x}$ species. J. Atmos. Chem. Phys. 4, 1461-1738 (2004)

Atwater, M.A., Brown, P.S.: Numerical computations of the latitudinal variation of solar radiation for an atmosphere of varying opacity. J. Appl. Meteorol. 13, 289-297 ( 1974)

Bais, A.F., Madronich, S., Crawford, J., Hall, S.R., Mayer, B., van Weele, M., Lenoble, J., Calvert, J.G., Cantrell, C.A., Shetter, R.E., Hofzumahaus, A., Keopke, P., Monks, P.S., Frost, G., McKenzie, R., Krotkov, N., Kylling, A., Swartz, W.H., Lloyd, S., Pfister, G., Martin, T.J., Roeth, E.-P., Griffioen, E., Ruggaber, A., Krol, M., Kraus, A., Edwards, G.D., Mueller, M., Lefer, B.L., Johnston, P., Schwander, H., Flittner, D., Gardiner, B.G., Barrick, J., Schmitt, R.: International Photolysis Frequency Measurement and Model Intercomparison (IPMMI): Spectral actinic solar flux measurements and modeling. J. Geophys. Res.Atmos. 108, IPM 2-1-2-20 (2003)

Balis, D.S., Zerefos, C.S., Kourtidis, K., Bais, A.F., Hofzumahaus, A., Kraus, A., Schmitt, R., Blumthaler, M., Gobbi, G.P.: Measurements and modeling of photolysis rates during the Photochemical Activity and Ultraviolet Radiation (PAUR) II campaign. J. Geophys. Res. 107, PAU 5-1-5-12 (2002)

Becker, K.H., Kleffmann, J., Kurtenbach, R., Wiesen, P., Febo, A., Gherardi, M., Sparapani, R.: Line strength measurements of trans-HONO near $1255 \mathrm{~cm}^{-1}$ by tunable diode laser spectrometry. Geophys. Res. Lett. 22, 2485-2488 (1995)

Bongartz, A., Kames, J., Welter, F., Schurath, U.: Near-uv absorption cross sections and trans/cis equilibrium of nitrous acid. J. Phys. Chem. 95, 1076-1082 (1991)

Bongartz, A., Kames, J., Schurath, U., George, C., Mirabel, P., Ponche, J.L.: Experimental determination of HONO mass accommodation coefficients using two different techniques. J. Atmos. Chem. 18, 149-169 (1994)

Brust, A.S., Becker, K.H., Kleffmann, J., Wiesen, P.: UV absorption cross sections of nitrous acid. Atmos. Environ. 34, 13-19 (2000)

Cantrell, C.A., Calvert, J.G., Bais, A., Shetter, R.E., Lefer, B.L., Edwards, G.D.: Overview and conclusions of the International Photolysis Frequency Measurement and Modeling Intercomparison (IPMMI) study. J. Geophys. Res.-Atmos. 108, IPM 1-1-1-16 (2003)

Chambers, L.H., Wielicki, B.A., Evans, K.F.: Accuracy of the independent pixel approximation for satellite estimates of oceanic boundary layer cloud depth. J. Geophys. Res. 102, 1779-1794 (1997)

Cotte, H.: Thesis report, University of Paris VII. Paris, France (1995)

Cotte, H., Devaux, C., Carlier, P.: Transformation of irradiance measurements into spectral actinic flux for photolysis rates determination. J. Atmos. Chem. 26, 1-28 (1997)

Cox, R.A., Derwent, R.G.: The ultra-violet absorption spectrum of gaseous nitrous acid. J. Photochem. 6, 23-34 $(1976,1977)$ 
Crawford, J., Shetter, R.E., Lefer, B., Cantrell, C., Junkermann, W., Madronich, S., Calvert, J.: Cloud impacts on UV spectral actinic flux observed during the International Photolysis Frequency Measurement and Model Intercomparison (IPMMI). J. Geophys. Res.-Atmos. 108(D16), 8545 (2003)

Dahlback, A., Stamnes, K.: A new spherical model for computing the radiation field available for photolysis and heating at twilight. Planet Space Sci. 39, 671-683 (1991)

Darsey, J.A., Thompson, D.L.: Ab initio molecular orbital calculation of the HONO torsional potential. J. Phys. Chem. 91, 3168-3171 (1987)

DeLuisi, J.J., Mateer, C.L.: On the application of the optimum statistical inversion technique to the evaluation of Umkehr observations. J. Appl. Meteorol. 10, 328-334 (1971)

Demerjian, K.L., Schere, K.L., Peterson, J.T.: Theoretical estimates of actinic (spherically integrated) flux and photolytic rate constants of atmospheric species in the lower troposphere. Adv. Environ. Sci. Technol. 10, $369-459$ (1980)

DeMore, W.B., Sander, S.P., Golden, D.M., Hampson, R.F., Kurylo, M.J., Howard, C.J., Ravishankara, A.R., Kolb, C.E., Molina, M.J.: Chemical kinetics and photochemical data for use in stratospheric modeling, Evaluation Number 11, JPL Publ. 94-26, National Aeronautics and Space Administration (NASA)/Jet Propulsion Laboratory (JPL) (1994)

DeMore, W.B., Sander, S.P., Golden, D.M., Hampson, R.F., Kurylo, M.J., Howard, C.J., Ravishankara, A.R., Kolb, C.E., Molina, M.J.: Chemical kinetics and photochemical data for use in stratospheric modeling. Evaluation Number 12, JPL Publ. 97 - 4, National Aeronautics and Space Administration (NASA)/Jet Propulsion Laboratory (JPL) (1997)

Dickerson, R.R. Stedman, D.H.: Precision of $\mathrm{NO}_{2}$ photolysis rate measurements. Environ. Sci. Technol. 14, 1261-1262 (1980)

d'Or, L., Tarte, P.: Spectroscopic studies of nitrous acid. The infrared spectrum of gaseous nitrous acid. Bull. Soc. Roy. Sci. Liège 20, 478-496 (1951)

Elterman, L.: UV, visible, and IR attenuation for altitudes to $50 \mathrm{~km}$. Air Force Cambridge Research Laboratories (AFCRL) Report -68-0153, Cambridge, MA (1968)

Febo, A., Perrino, C., Gherardi, I. M., Sparapani, R.: Evaluation of a high-purity and high-stability continuous generation system for nitrous acid. Environ. Sci. \& Techn. 29, 2390-2395 (1995)

Fiocco, G., Mugnai, A., Forlizzi, W.: Effects of radiation scattered by aerosols on the photodissociation of ozone. J. Atmos. Terr. Phy. 40, 949-961 (1978)

Hall, R.T., Pimentel, G.C.: Isomerization of nitrous acid: An infrared photochemical reaction. J. Chem. Phys. 38, 1889-1897 (1963)

Harris, G.W., Carter, P.L., Winer, A.M., Pitts, J.N., Platt, U., Perner, D.: Observations of nitrous acid in the Los Angeles atmosphere and implications for predictions of ozone-precursor relationships. Environ. Sci. Technol. 16, 414-419 (1982)

Haurwitz, B.: Isolation in Relation to Cloud Type, J. Meteorol. 5, 110-113 (1948)

Heland, J., Kleffmann, J., Kurtenbach, R., Wiesen, P.: A new instrument to measure gaseous nitrous acid (HONO) in the atmosphere. Environ. Sci. Technol. 35, 3207-3212 (2001)

Henyey, L.G. Greenstein, J.L.: Diffuse radiation in the galaxy. J. Astrophys. 93, 70 $83(1941)$

Hofzumahaus, A., Kraus, A., Müller, M.: Solar actinic flux spectroradiometry: A technique for measuring photolysis frequencies in the atmosphere. Appl. Opt. 38, 4443-4460 (1999)

Hofzumahaus, A., Kraus, A., Kylling, A., Zerefos, C.S.: Solar actinic radiation $(280-420 \mathrm{~nm})$ in the cloudfree troposphere between ground and $12 \mathrm{~km}$ altitude: Measurements and model results. J. Geophys. Res.Atmos. 107(D18), 8138 (2002)

Hofzumahaus, A., Lefer, B.L., Monks, P.S., Hall, S.R., Kylling, A., Mayer, B., Shetter, R.E., Junkermann, W., Bais, A., Calvert, J.G., Cantrell, C.A., Madronich, S., Edwards, G.D., Kraus, A., Müller, M., Bohn, B., Schmitt, R., Johnston, P., McKenzie, R., Frost, G.J., Griffioen, E., Krol, M., Martin, T., Pfister, G., Röth, E.P., Ruggaber, A., Swartz, W.H., Lloyd, S.A., VanWeele, M.: Photolysis frequency of $\mathrm{O}_{3}$ to $\mathrm{O}\left({ }^{l} \mathrm{D}\right)$ : measurements and modeling during the International Photolysis Frequency Measurement and Modeling Intercomparison (IPMMI). J. Geophys. Res.- Atmos. 109, D08590 (2004)

Holland, F., Hofzumahaus, A., Schafer, J., Kraus, A., Patz, H.W.: Measurements of $\mathrm{OH}$ and $\mathrm{HO}_{2}$ radical concentrations and photolysis frequencies during BERLIOZ. J. Geophys. Res.-Atmos. 108(D4), 8246 (2003)

Huang, G., Zhou, X., Deng, G., Huancheng, Q., Civerolo, K.: Measurements of atmospheric nitrous acid and nitric acid. Atmos. Environ. 36, 2225-2235 (2002)

Jackson, J.O., Stedman, D.H., Smith, R.G., Hocker, L.H., Warner, P.O.: Direct $\mathrm{NO}_{2}$ photolysis rate monitor. Rev. Sci. Instrum. 46, 376-378 (1975)

Johnston, H.S., Graham, R.: Photochemistry of $\mathrm{NO}_{x}$ and $\mathrm{HNO}_{x}$ compounds. Can. J. Chem. 52, 1415-1423 (1974) 
Jones, L.H., Badger, R.M., Moore, G.E.: The infrared spectrum and the structure of gaseous nitrous acid. J. Chem. Phys. 19, 1599 - 1604 (1951)

Joseph, J.H., Wiscombe, W.J., Weinman, J.A.: The delta-eddington approximation for radiative flux transfer. J. Atmos. Sci. 33, 2452-2459 (1976)

Junkermann, W., Platt, U., Volz-Thomas, A.: A photoelectric detector for the measurement of photolysis frequencies of ozone and other atmospheric molecules. J. Atmos. Chem. 8, 203-227 (1989)

Junkermann, W., Brühl, C., Perner, D., Eckstein, E., Trautmann, T., Früh, B., Dlugi, R., Gori, T., Ruggaber, A., Reuder, J., Zelger, M., Hofzumahaus, A., Kraus, A., Rohrer, F., Brüning, D., Moortgat, G., Horowitz, A., Tadić, J. : Actinic radiation and photolysis processes in the lower troposphere: Effect of clouds and aerosols. J. Atmos. Chem. 42, 413-441 (2002)

Kaiser, E.W., Wu, C.H.: A kinetic study of the gas phase formation and decomposition reactions of nitrous acid. J. Phys. Chem. 81, 1701-1705 (1977)

Kleffmann, J., Heland, J., Kurtenbach, R., Lorzer, J., Wiesen, P.: A new instrument (LOPAP) for the detection of nitrous acid (HONO). Environ. Sci. Pollut. Res. Int. Sp. Iss. 4, 48-54 (2002)

Kraus, A., Hofzumahaus, A.: Field measurements of atmospheric photolysis frequencies for $\mathrm{O}_{3}, \mathrm{NO}_{2}, \mathrm{HCHO}$, $\mathrm{CH}_{3} \mathrm{CHO}, \mathrm{H}_{2} \mathrm{O}_{2}$, and HONO by UV spectroradiometry. J. Atmos. Chem. 31, 161-180 (1998)

Kraus, A., Rohrer, F., Hofzumahaus, A.: Intercomparison of $\mathrm{NO}_{2}$ photolysis frequency measurements by actinic flux spectroradiometry and chemical actinometry during JCOM97. Geophys. Res. Lett. 27, 1115$1118(2000)$

Kylling, A., Webb, A. R., Kift, R., Gobbi, G. P., Ammannato, L., Barnaba, F., Bais, A., Kazadzis, S., Wendisch, M., Jakel, E., Schmidt, S., Kniffka, A., Thiel, S., Junkermann, W., Blumthaler, M., Silbernagl, R., Schallhart, B., Schmitt, R., Kjeldstad, B., Thorseth, T. M., Scheirer, R., Mayer, B.: Spectral actinic flux in the lower troposphere: Measurement and 1-D simulations for cloudless, broken cloud and overcast situations. Atmos. Chem. \& Phys. 5, 1975-1997 (2005)

Lantz, K. O., Shetter, R. E., Cantrell, C. A., Flocke, S. J., Calvert, J. G., Madronich, S.: Theoretical, actinometric, and radiometric determinations of the photolysis rate coefficient of $\mathrm{NO}_{2}$ during the Mauna Loa Observatory Photochemistry Experiment 2. J. Geophys. Res. 101, 14613-14629 (1996)

Madronich, S.: Photodissociation in the atmosphere, 1., Actinic flux and the effects of ground reflections and clouds. J. Geophys. Res. 92, 9740-9752 (1987)

Madronich, S., Flocke, S.: The role of solar radiation in atmospheric chemistry. in Handbook of Environmental Chemistry, Environmental Photochemistry, Vol. 2, ed. P. Boule, Springer, Verlag, New York, pp. 1-26 (1998)

McGraw, G.E., Bernitt, D.L., Hisatsune, I.C.: Infrared spectra of isotopic nitrous acids. J. Chem. Phys. 45, 1392-1399 (1966)

Molina, L.T., Molina, M.J.: Absolute absorption cross sections of ozone in the $185-350-n m$ wavelength range. J. Geophys. Res. 91, 14,501-14,508 (1986)

Müller, M., Kraus, A., Hofzumahaus, $\mathrm{A} .: \mathrm{O}_{3}$ to $\mathrm{O}(1 \mathrm{D})$ photolysis frequencies determined from spectroradiometer measurements of solar actinic UV radiation: Comparison with chemical actinometer measurements. Geophys. Res. Lett. 22, 679-682 (1995)

Nicolet, M.: On the molecular scattering in the terrestrial atmosphere: An empirical formula for its calculation in the homosphere. Planet Space Sci. 32, 1467-1468 (1984)

Pagsberg, P., Bjergbakke, E., Ratajczak, E., Sillesen, A.: Kinetics of the gas phase reaction $\mathrm{OH}+\mathrm{NO}(+\mathrm{M}) \rightarrow$ $\mathrm{HONO}(+\mathrm{M})$ and the determination of the UV absorption cross sections of HONO. Chem. Phys. Lett. 272, 383-390 (1997)

Perner, D., Platt, U.: Detection of nitrous acid in the atmosphere by differential optical absorption. Geophys. Res. Lett. 6(12), 917-920 (1979)

Platt, U.: Modern methods of the measurement of atmospheric trace gases: Invited lecture. Phys. Chem. Chem. Phys. 1, 5409-5415 (1999)

Shetter, R.E., MacDaniel, A.H., Cantrell, C.A., Madronich, S., Calvert, J.G.: Actinometer and Eppley radiometer measurements of the $\mathrm{NO}_{2}$ photolysis rate coefficient during MLOPEX. J. Geophys. Res. 97, $10349-10360(1992)$

Shetter, R.E., Müller, M.: Photolysis frequency measurements using actinic flux spectroradiometry during the PEM-Tropics mission: Instrumentation description and some results. J. Geophys. Res. Atmos. 104, 5647-5661 (1999)

Shetter, R.E., Cinquini, L., Lefer, B.L., Hall, S.R., Madronich, S.: Comparison of airborne measured and calculated spectral actinic flux and derived photolysis frequencies during the PEM Tropics B mission. J. Geophys. Res. - Atmos. 107, 8234 (2002)

Sickles, J.E., II, Jeffries, A.E.: Development and operation of a Device for the Continuous Measurement of $\phi \mathrm{k}_{a}$ for Nitrogen Dioxide. ESE Publ. No. 396, University of North Carolina, Chapel Hill, N.C. (1975) 
Sidman, J.W.: Electronic transitions due to nonbonding electrons carbonyl, aza-aromatic, and other compounds. Chem. Rev. 58, 689-713 (1958)

Stamnes, K., Tsay, S.-C., Wiscombe, W., Jayaweera, K.: Numerically stable algorithm for discrete-ordinatemethod radiative transfer in multiple scattering and emitting layered media. Appl. Opt. 27(12), 2502-2509 (1988)

Stephens, G.L., Tsay, S.-C.: On the cloud absorption anomaly. Q.J.R. Meteorol. Soc. 116, 671-704 (1990)

Steinfeld, J.I.: Molecules and radiation: An introduction to modern molecular spectroscopy, Harper \& Row: New York (1974)

Stockwell,W.R., Calvert, J.G.: The near ultraviolet absorption spectrum of gaseous $\mathrm{HONO}$ and $\mathrm{N}_{2} \mathrm{O}_{3}$. J. Photochem. 8, 193-203 (1978)

Stutz, J., Kim, E.S., Platt, U., Bruno, P., Perrino, C., Febo, A.: UV-visible absorption cross sections of nitrous acid. J. Geophys. Res. 105(D11), 14,585-14,592 (2000)

Thorne, A.P.: Spectrophysics, 2nd ed., Chapman and Hall, London (1988)

US Standard Atmosphere: National Oceanic and Atmospheric Administration (NOAA), National Aeronautics and Space Administration (NASA). United States Air Force, Washington, DC (1976)

Van der Hage, J.C., Boot, W., Van Drop, H., Duykerke, P.G., Vilà Guerau de Arellano, J.: A photoelectric detector suspended under a balloon for actinic flux measurements. J. Atmos. Chem. 11, 674-680 (1994)

Varma, R., Curl, R.F.: Study of the $\mathrm{N}_{2} \mathrm{O}_{3}-\mathrm{H}_{2} \mathrm{O}-\mathrm{HNO}_{2}$ equilibrium by intensity measurements in microwave spectroscopy. J. Phys. Chem. 80, 402-409 (1976)

Vasudev, R.: Absorption spectrum and solar photodissociation of gaseous nitrous acid in the actinic wavelength region. Geophys. Res. Lett. 17(12), 2153-2155 (1990)

Wallington, T.J., Japar, S.M.: Fourier Transform Infrared kinetic studies of the reaction of $\mathrm{HONO}$ with $\mathrm{HNO}_{3}$, $\mathrm{NO}_{3}$, and $\mathrm{N}_{2} \mathrm{O}_{5}$ at $298 \mathrm{~K}$. J. Atmos. Chem. 9, 399-409(1989)

World Meteorological Organization (WMO), Atmospheric ozone.: Global ozone research and monitoring project, Rep. 16, Geneva, Switzerland (1985)

Zafonte, L., Rieger, P.L., Holmes, J.R.: Nitrogen dioxide photolysis in the Los Angeles atmosphere. Environ. Sci. Techn. 11, 483-487 (1977)

Zeng, J., Madronich, S., Stamnes, K.: A note on the use of the two-stream delta-scaling approximation for calculating atmospheric photolysis rate coefficients. J. Geophys. Res. 101(D9), 14,525-14,530 (1996) 